Click www.researchjournal.co.in/online/subdetail.html to purchase.

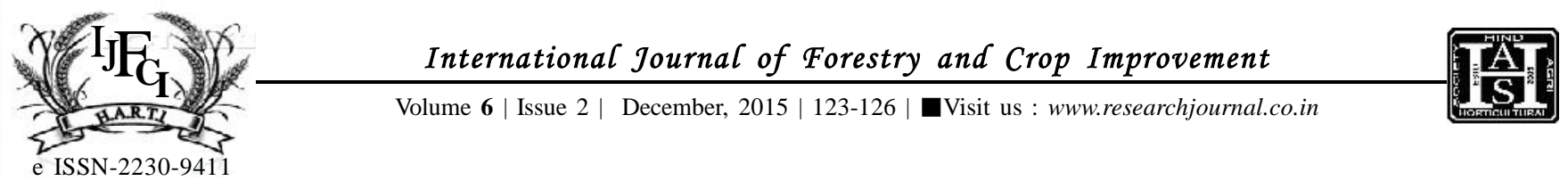

RESEARCH ARTICLE

DOI: $10.15740 / \mathrm{HAS} / \mathrm{IJFCI} / 6.2 / 123-126$

\title{
Suitability of different crops and cropping systems for contingency crop planning
}

\author{
A.V. WAKURE, R.M. DHEWARE and R.G. BHAGYAWANT
}

\begin{abstract}
The experiment was conducted at the Dry Land Agricultural Research Centre, Vasantrao Naik Marathwada Agricultural University, Parbhani during Kharif and Rabi seasons of 2006-2007 and 2007-2008. Eight different promising cropping systems of important crop of Marathwada region were tested in varied weather condition under rain fed agriculture. At the end of two year experiment it was investigated that, sowing of all the cropping systems in $26^{\text {th }} \mathrm{MW}$ recorded the highest mean productivity as compared to delayed sowing after $26^{\text {th }}$ MW. The data further revealed that the parlimillet + pigeonpea $\left(\mathrm{C}_{5}\right)$, sorghum + pigeonpea $\left(\mathrm{C}_{4}\right)$, greengram - Rabi sorghum $\left(\mathrm{C}_{8}\right)$, soybean + pigeonpea $\left(\mathrm{C}_{6}\right)$ showed the better performance over the sowing dates as compared to all the other cropping systems.The lowest mean productivity of $537 \mathrm{~kg} / \mathrm{ha}$ was obtained when sorghum + pigeonpea ICS sown in $32^{\text {nd }} \mathrm{MW}\left(\mathrm{D}_{4} \mathrm{C}_{4}\right)$ followed by $\mathrm{D}_{4} \mathrm{C}_{1}, \mathrm{D}_{4} \mathrm{C}_{7}, \mathrm{D}_{3} \mathrm{C}_{1}$ and $\mathrm{D}_{3} \mathrm{C}_{4}$ treatment combinations.
\end{abstract}

KEY WORDS : Suitability, Crops, Cropping systems, Contingency crop planning

How TO CITE THIS ARTICLE : Wakure, A.V., Dheware, R.M. and Bhagyawant, R.G. (2015). Suitability of different crops and cropping systems for contingency crop planning. Internat. J. Forestry \& Crop Improv., 6 (2) : 123-126.

ARTICle ChroniCAL : Received : 15.09.2015; Revised : 15.11.2015; Accepted : 26.11.2015 